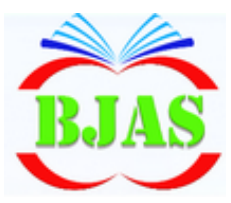

ISSN $1814-\mathbf{5 8 6 8}$
Available online at: http//bjas.bajas.edu.iq

College of Agriculture, University of Basrah

DOi:10.21276/basjas

\title{
Evaluation of Shatt Al-Arab River Using Organic Pollution Index
}

\author{
Nada M. Al-Baghdadi' ${ }^{1 *}$, Abdul Aziz M. Abdullah² and Entisar N. Sultan² \\ ${ }^{1}$ Department of Marine Biology, Marine Science Centre, University of Basrah, Iraq \\ ${ }^{2}$ Department of Fisheries and Marine Resources, College of Agriculture, University \\ of Basrah, Iraq.
}

*Corresponding author e-mail: nadamofeed@gmail.com

Received 10 May 2019; Accepted 5 July 2019; Available online 18 September 2019

\begin{abstract}
The current study has evaluated Shatt Al-Arab water using organic pollution index. The study included three stations, the first Al-Sharash, the second AlSalhiya and the third area Al-Dweab. Water samples were monthly collected from December 2017 to November 2018. Five environmental parameters were used to calculate the organic pollution index (OPI) including Biological Oxygen Demand (BOD), Chemical Oxygen Demand (COD), Active nitrate $\left(\mathrm{NO}_{3}\right)$, Ammonium ion $\left(\mathrm{NH}_{4}\right)$ and Total Phosphate (TP). The highest biological oxygen demand was $9 \mathrm{mg} . \mathrm{l}^{-1}$ at AlSharash station in July and the lowest values $1 \mathrm{mg} .1^{-1}$ in the Al- Dweab station during December, January, February and April. The highest chemical oxygen demand (250 mg. $1^{-1}$ was recorded at Al-Sharash station in September and the lowest value was 6.2 mg. $\mathrm{l}^{-1}$ in Al-Dweab station during December. Nitrates was recorded the highest value $41.51 \mathrm{mg}$ nitrogen-nitrate. $\mathrm{l}^{-1}$ at Al-Salhiya station in May and lowest value $1.49 \mathrm{mg}$ nitrogen- nitrate. $\mathrm{l}^{-1}$ at Al-Sharash station during December. The ammonium ion was recorded in highest value $7.7 \mathrm{mg} . \mathrm{l}^{-1}$ at Al- Salhiya station in December and the lowest value $0.5 \mathrm{mg}$. $\mathrm{l}^{-1}$ at Al-Sharash station during June, while phosphate value was 0.23 and $1.99 \mathrm{mg} . \mathrm{l}^{-1}$ were recorded at Al-Sharash station in August and July respectively. The highest value of organic pollution index was 2.56 at Al-Salihiya station in August and lowest value 0.69 in the Al-Dweab station in April, while the annual rate of organic pollution index for the first, second and third stations were 1.55, 1.81 and 1.47 respectively, and 1.61 for Shatt Al-Arab water.
\end{abstract}

Key words: Shatt Al-Arab river, Water pollution, OPI.

\section{Introduction}

The Shatt Al-Arab river is recently suffering from a significant decline in its water quality as a result of several hydrological projects constructed by neighboring countries (Partow, 2001), as well as the continuous exposure of various sources of pollution, such as domestic, agricultural and industrial wastes (Al-Hejuje, 1997; Mahmood, 2008). There are several studies indicated the degradation of water quality of the Shatt Al-Arab (AlHejuje, 2014Moyel and Hussain, 2015; Yaseen et al., 2016).

There are many studies on organic pollution. Dejoux et al. (1981) observed that the pollution of urban water in general is an organic source and depends heavily on the 
size of development, expansion of population, urban, the absence of domestic and industrial waste treatment systems. Onyema et al. (2007) showed that increasing human activities are driving large quantities of compounds, including phosphates and nitrogen, into rivers and canals in Lagos city, Nigeria.

Radwan (2007) referred on his study on the Nile river that the inflow of organic materials in large quantities to the water has effects on the balance of the environment. Locally, Ahmed (2017) studied the effect of organic pollution on the composition of the small fish community in the nursery areas of Al-Meshab and Sindbad stations, the author observed a slight increase in the level of organic pollution during the summer months. AlHejuje (2014) and Al-Kanani (2017) also studied the organic pollution of the Shatt AlArab water pollution and found that the highest values of organic pollution index were in Al-Baradhiya. Al-Aboodi et al. (2018) cited that the organic pollution index for seventeen physical and chemical factors related to Shatt Al-Arab water for various purposes. The use of organic pollution index depends on the selection of environmental variables. Saleem \& Hussain (2013) used biological oxygen demands, active phosphate, ammonium ion and active nitrates in calculation of the organic pollutant index in the Shatt Al-Arab, Al-Hejuje (2014) calculated OPI in based on ammonium ion, biological oxygen demands, nitrite and active phosphate. Ahmed (2015) used nitrates, nitrite and active phosphates in calculation of the organic pollutant index in Shatt Al-Arab, Nazal (2016) used nitrate, active phosphate and biological oxygen demands in calculation of the organic pollution index in the southeast of Hor Al-Hammer. Al-Kanani (2017) used nitrate, active phosphates, ammonium ion and biological oxygen demands in calculation of the organic pollution index in a Shatt Al-Arab river. The present study aims to evaluate water quality of Shatt Al-Arab river in the stations of Al-Sharash, Al-Salihiya and Al-Dweab by applying organic pollution index (OPI).

\section{Materials \& Methods \\ Description of study area}

The first station (Al-Sharash) is located in south Qurna within the coordinates $\mathrm{N} 30^{\circ} 50^{\prime} 50.896^{\prime \prime} \mathrm{E} 47^{\circ} 47^{\prime} 47.252^{\prime \prime}$. It is characterized by a low slope of the coast and open coastal gradient and presence of several types of high density plants. The second station (Al-Salhiya) is located in the AlSalhiya area within the coordinates N30 50'50.896" E47 85'85.736", opposite AlSader educational hospital on the eastern side of the river. It characterized by presence of variety and density of aquatic organic pollution. Third station (Al-Dweab) is located in Al-Dweab area within the coordinates $30^{\circ} 10^{\prime} 10.569^{\prime \prime} \mathrm{N}$ and $48^{\circ} 39^{\prime} 39.993^{\prime \prime} \mathrm{E}$. It characterized by its varying intensity compared with the previous stations because the area is not populated (Fig. 1).

\section{Water samples collection}

Monthly water samples were collected for a period from December, 2017 to November, 2018 during the lowest tide using polyethylene bottles with three replication per site and they kept in a cold box until arrived to the laboratory.

Biological oxygen demand was calculated in laboratory using WTW TS 606/2-i device with a digital scale (OxiTop). The chemical oxygen demand calculated using COD Kits according to Titrimetric Closed Reflux method, using a COD reactor and total phosphate and ammonium ion estimated as 
described in APHA (2005). Strickland \& Parsons (1972) used to measure the amount of active nitrates, while organic pollution index applied according to Boluda et al. (2002) as follows:

$$
\mathrm{OPI}=\left(\sum_{i=1}^{n} \frac{C \mathrm{i}}{C m i}\right) / n
$$

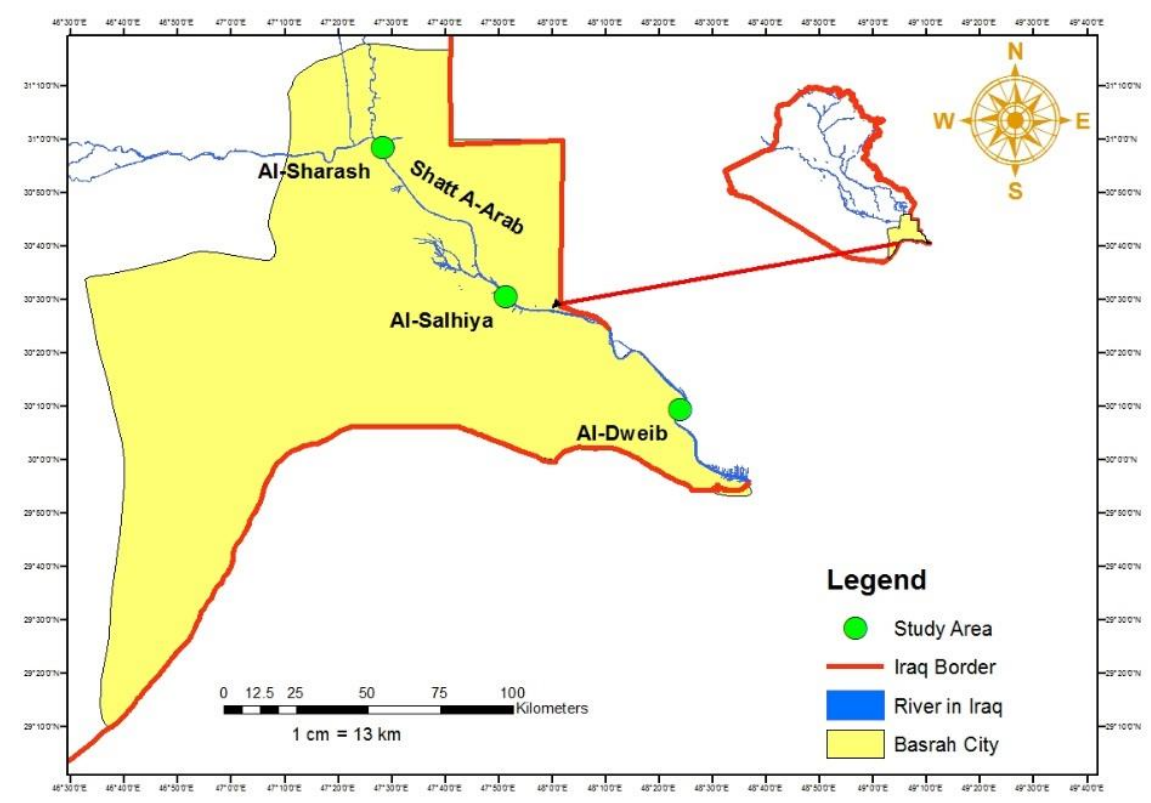

Fig. (1) Map showing the study sites on the Shatt Al-Arab river.

Table (1). The permitted limits locally and globally.

\begin{tabular}{ccc}
\hline \multicolumn{2}{c}{ Permissible limits } & $\begin{array}{l}\text { Criteria } \\
\left(\mathrm{mg.l}^{-1}\right)\end{array}$ \\
\cline { 1 - 2 } $\begin{array}{c}\text { EPA } \\
(2001)\end{array}$ & $\begin{array}{l}\text { Iraqi } \\
\text { standards } \\
\text { metrology } \\
(1980)\end{array}$ & \\
\hline- & $<5$ & $\mathrm{BOD}_{5}$ \\
\hline- & $<100$ & $\mathrm{COD}^{2}$ \\
\hline $0.76^{*}$ & 15 & $\mathrm{NO}_{3}$ \\
\hline 0.13 & 0.4 & $\mathrm{TP}^{+}$ \\
\hline- & 1 & $\mathrm{NH}_{4}$ \\
\hline
\end{tabular}

*Total Nitrogen

In the current study, the criteria of System of river maintenance from pollution for Iraqi Standard and Metrology (1980) and the US Environmental Protection Agency standards EPA (2001) have been used. (Table $1)$.
Where:

Ci: The experimental value of each analytical parameter

Cmi: maximum tolerate value of $\mathrm{Ci}$

$\mathrm{n}$ : Number of analytical parameters.

If: One value > 1 for OPI, this indicates contamination (Boluda et al., 2002).

\section{Results}

\section{Environmental factors limited to OPI} values:

The results showed spatial and temporal fluctuations in environmental variables during the study period as shown in figs (2-6).

\section{Monthly changes of OPI values:}

The values of the OPI showed clear fluctuations during the study period (Fig. 7). The values of organic pollution index at AlSharash station ranged between 0.87- 2.46 during January and July, in Al-Salhia station was between 1.19-2.56 during January and August, in the Al-Dweab station was between 0.69-2.14 during April and November.

\section{Annual changes of OPI values}

The values of the annual organic pollution index fluctuated in the study stations (Fig. 8). 
Al-Baghdadi et al. / Basrah J. Agric. Sci., 32 (Special Issue): 153-162, 2019

The highest values (1.81) were recorded at Al-Salhia station and lowest values (1.47) at the Al-Dweab station. The annual average of three stations which represent Shatt Al-Arab was 1.61 .

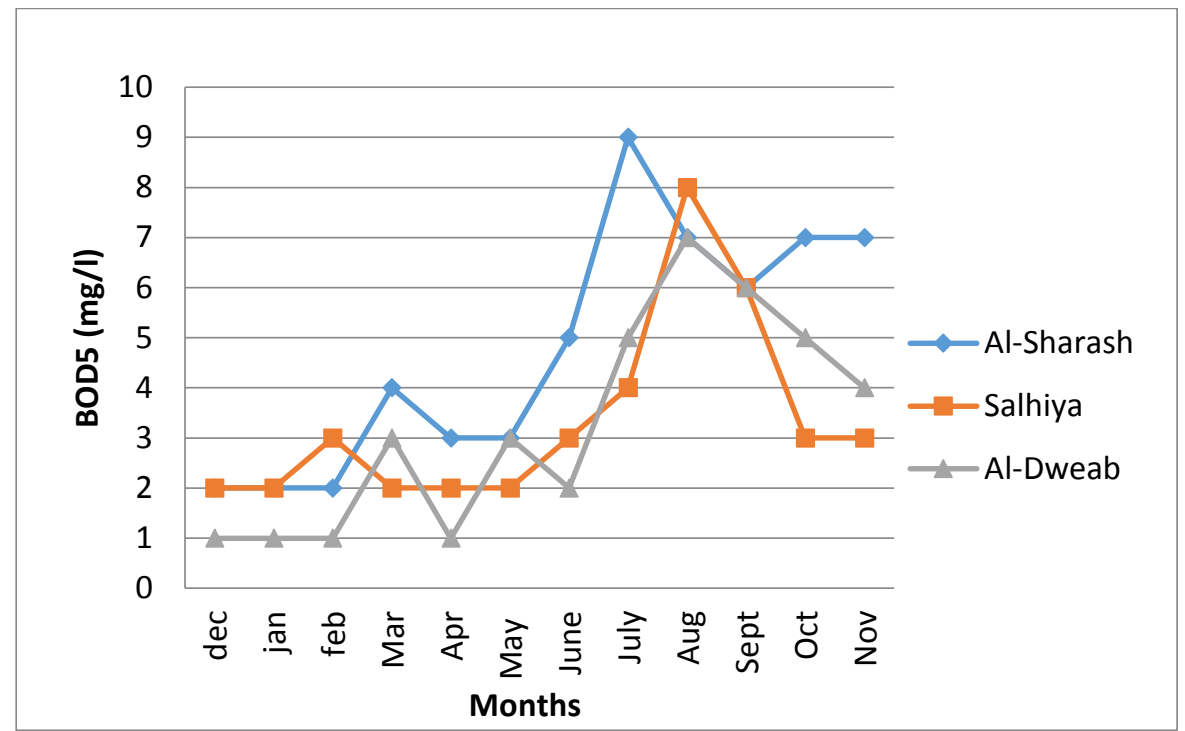

Fig. (2): Monthly variations of biological oxygen demand values $\left(\mathrm{mg.l}^{-1}\right)$ in the study stations.

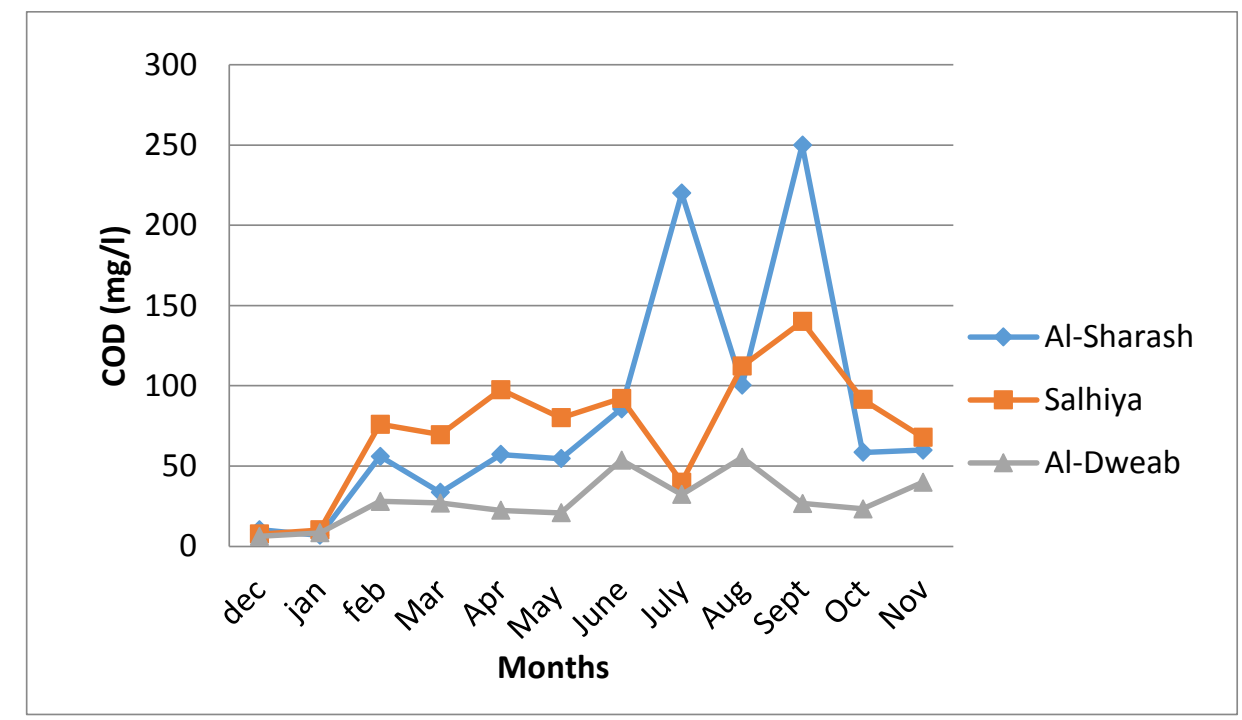

Fig. (3): Monthly variations of chemical oxygen demand values $\left(\mathrm{mg.l}^{-1}\right)$ in the study stations. 
Al-Baghdadi et al. / Basrah J. Agric. Sci., 32 (Special Issue): 153-162, 2019

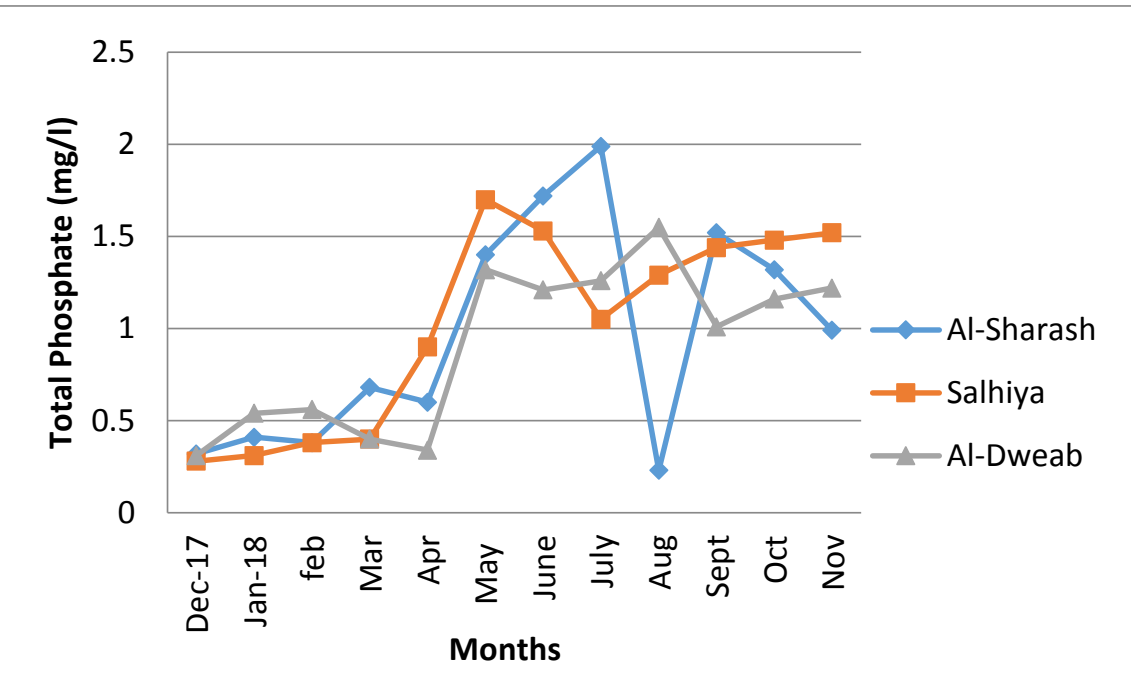

Fig. (4): Monthly variations of the total phosphate values $\left(\mathrm{mg.l}^{-1}\right)$ in the study stations.

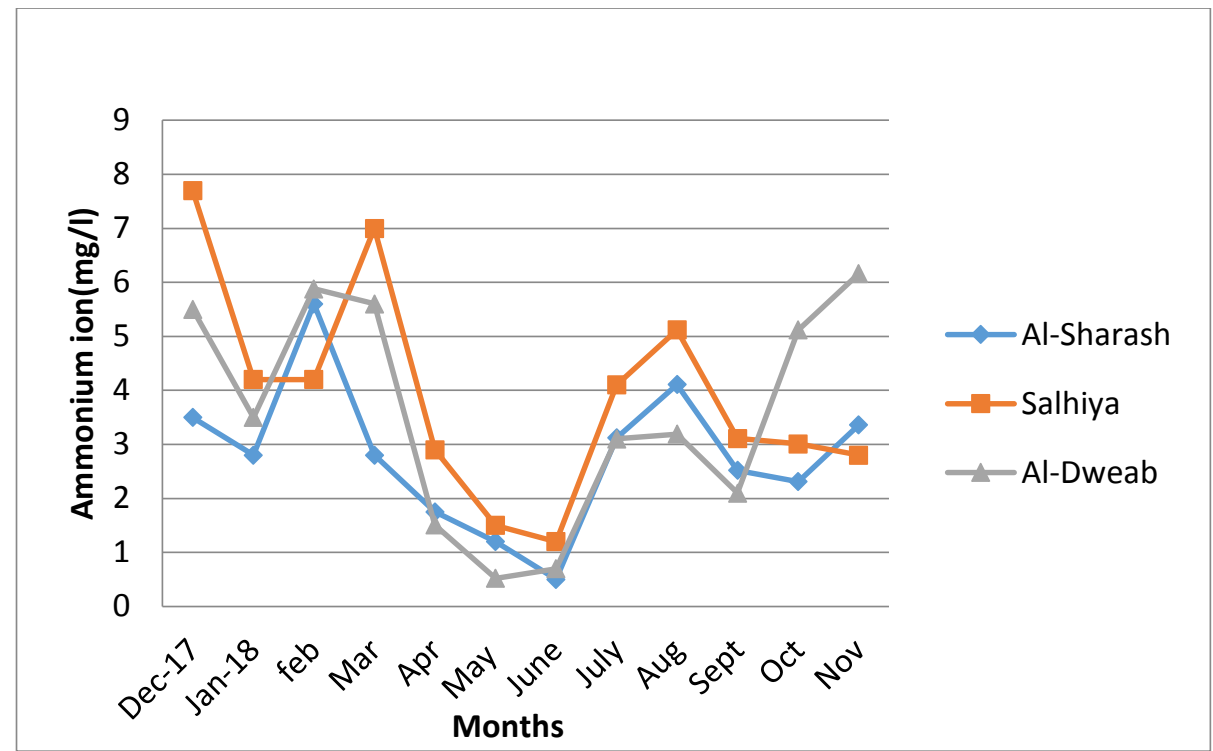

Fig. (5): Monthly variations of ammonium ion values (mg. $\left.\mathrm{l}^{-1}\right)$ in the study stations.

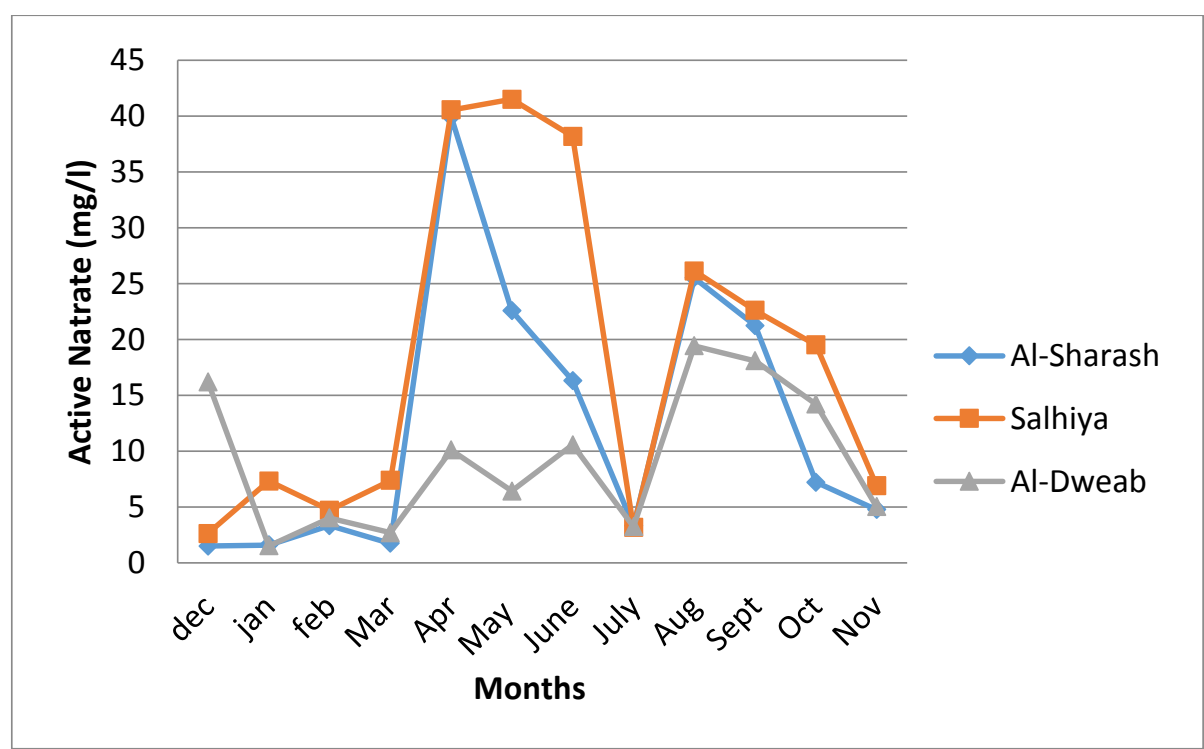

Fig. (6): Monthly variations of the active nitrate values $\left(\mathrm{mg.l}^{-1}\right)$ in the study stations. 


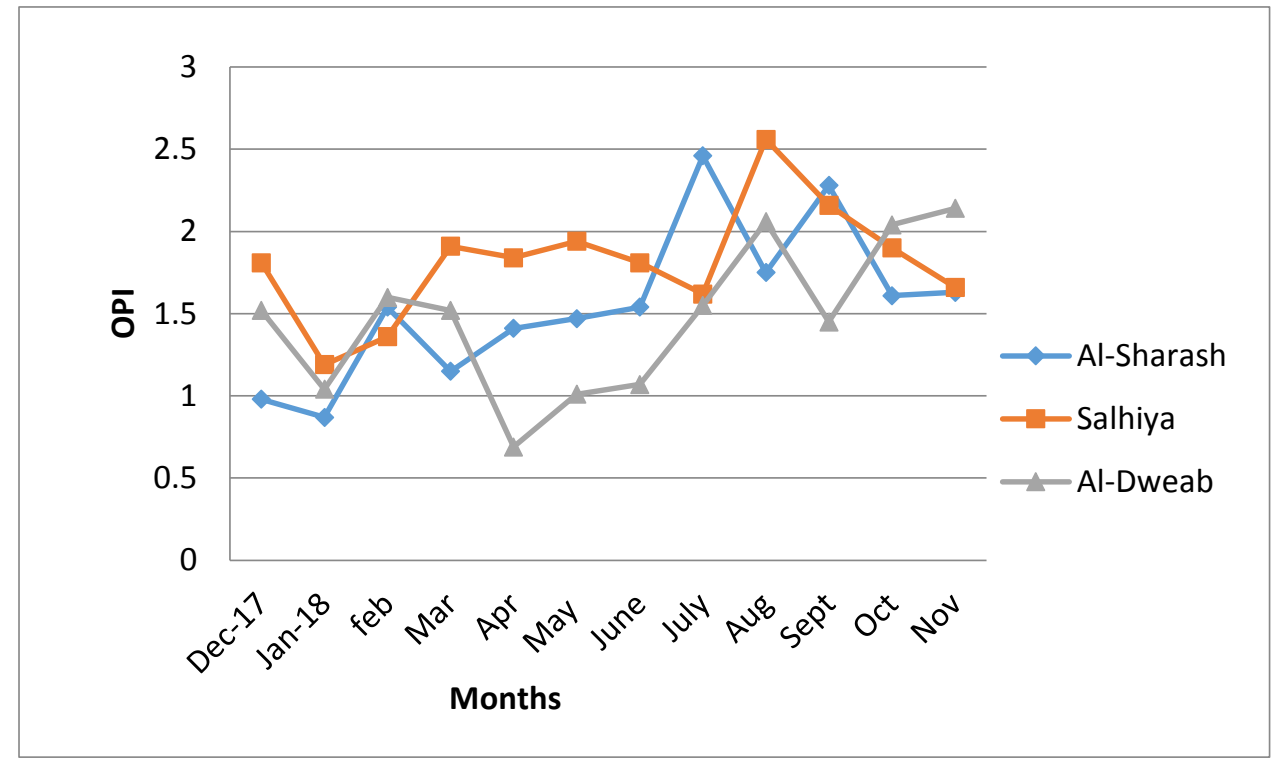

Fig. (7). Monthly variations of the organic pollution index in the study stations.

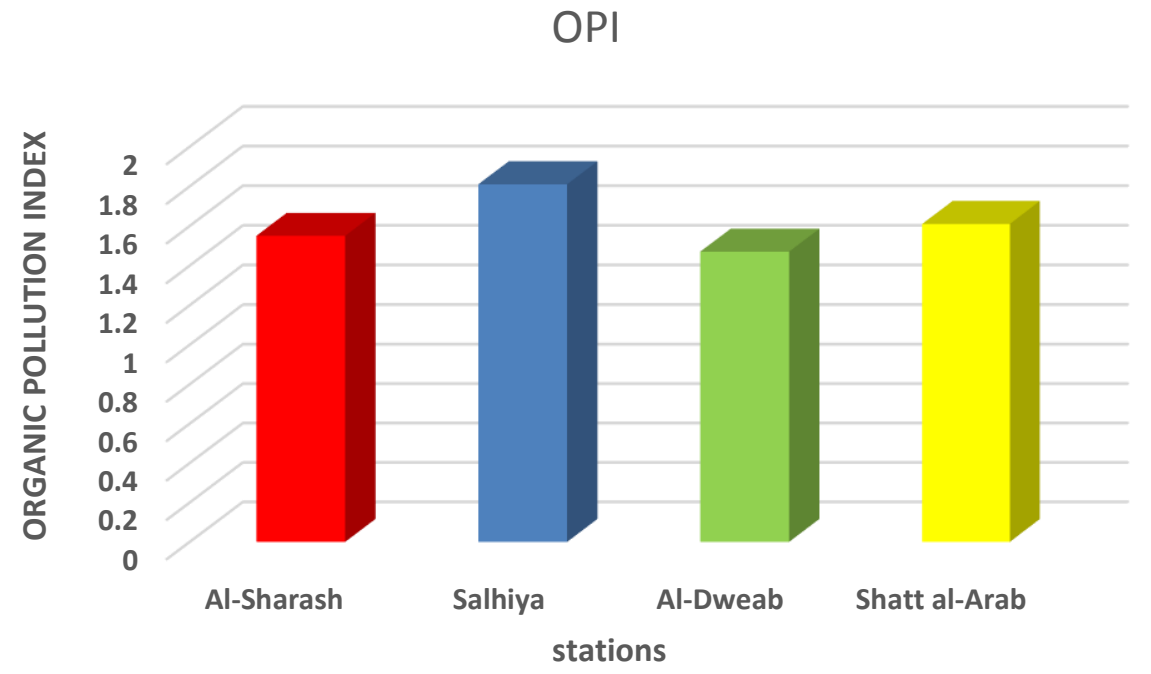

Fig. (8). Annual rate of organic pollution index in three stations and Shatt Al-Arab river.

\section{Discussion}

Biological oxygen demand $\left(\mathrm{BOD}_{5}\right)$ is a measure of the amount of dissolved oxygen that used by microorganisms to perform their metabolic processes and analyze organic matter that found in the water body (Al-Saadi, 2006). The current study showed low levels of $\mathrm{BOD}_{5} \mathrm{COD}$ during the cold months due to lack of microorganism activity at low temperatures, dilution of organic matter and rising water levels (Liu et al., 2000), while they increase during the hot months due to higher temperatures, which cause increase activity of microorganisms that consume dissolved oxygen, and also increasing the concentrations of pollutants as a result of the large decline of water levels (Prathumratana et al., 2008). The highest values of $\mathrm{BOD}_{5}$ was recorded at Al-Sharash and Al-Salihiya stations during the summer months because of increasing of effluents of organic materials in the river, the receipt of large quantities of 
wastewater, grazing areas of cows, buffaloes and boat residues.

Phosphorus is a nutrient that important for the growth of plants in the freshwater system (Varol et al., 2011). The present results showed increase of total phosphate concentrations during the summer months. The increase in phosphate concentrations during the hot months resulted in the release of phosphate from sediments (Rakocevic, 2012) and the degradation of organic matter because of increase microorganisms activities during hot months, decrease water levels, and evaporation processes. These results agree with Al-Shawi (1999) and Hameed \& Aljorany (2011).

The decrease in phosphate concentrations during spring for all stations may be due to their consumption by algae, aquatic plants (Faragallah et al., 2009). This agree with Hassan (2013) who found low concentration of total phosphorus in Shatt Al- Arab river, and decrease concentration of total phosphor at Al-Dweab station, which is the farthest point from the sources of effluent discharge, this is may be due to self-purification capacity of current which incoming from sea and dilution processes. This agree with Kuame et al. (2012).

The results of present study was showed significant fluctuations in values of ammonium ion during the months of year, which increased during the winter months gradually in all stations due to the lack activity of microorganisms during the cold months and the reduction of their needs for protein synthesis (Chang et al., 2006).

Al-Salhiya recorded the highest values in nitrate concentrations compared with the other stations, Al-Sharash and Al-Dweab. This is due to the increase in the discharge of sewage from untreated effluents of loaded with organic and inorganic compounds containing nitrogen compounds (Johnson \& Chase, 2004), in addition to rains drifts from organic compounds and nitrogen fertilizers from neighboring agricultural lands (Lomoljo et al., 2009). The decrease in the nitrate values in the winter months in the study stations may be due to the lack of activity of microorganisms and breakdown of organic matters that consumed by plants and phytoplankton (Antoine \& Al-Saadi, 1982; Davies et al., 1995).

The results of present study showed monthly and spatial variations in the values of the organic pollution index for all stations. The highest monthly and annual values of the organic pollution index were recorded at AlSalhiya station. This may be due to nature of the area, population density, restaurants and untreated wastewater flowing directly to the Shatt al-Arab (Al-Imarah et al., 2001), in addition to the agricultural waste, the waste of livestock and the ejected waste from hospitals. This is consistent with study of Saleem \& Hussein, 2013; Al-Kanani, 2017) while monthly and annual organic pollution index values were decreased at the third station (Al-Dweab). This decline of OPI may be due to the disruption of water payments coming from the Gulf and the dilution of Karun water, however, it is still within the minimum organic pollution due to the dumping of ships and activity boats within the area $_{2}$ wastewater from the city of AlMuhamara and Abadan refineries, another polluted sources that to the river. This study do not agree with what was found by AlKanani (2017) who referred that the two stations of Sindbad and Abi Al-Khaseeb had closed and less polluted values than the third station near Al-Sader hospital and do not agree with Saleem \& Hussein (2013); they showed that the lowest values for the OPI 
were at the station of Maqal. The highest values of OPI was recorded during the summer months because of the high temperatures which lead to the faster decomposition of organic matter and the higher the dissolved organic matter, the higher the organic pollution load (Rahul et al. 2013). This agree with Al-Aboodi et al. (2018) whom demonstrated the decrease in quality of the Shatt al-Arab water under the influence of a high level of organic pollution during the summer. The lowest value of OPI was in winter because of the lack of activity of microorganisms consequently the reduction of organic matter. This agree with Al-Hejuje (2014) finding. Our conclusion is consistent with Hassan (2013) who showing that the organic forms of phosphorus and nitrogen are predominant, confirming of presence organic pollution in the Shatt Al-Arab river.

\section{Conclusions}

It was noted that the Shatt Al-Arab river is organically contaminated and Al-Salhia was the worst polluted station.

\section{Acknowledgements}

Authors would thank to staff of Department of Fisheries and Marine Resources members College of Agriculture and Department of Marine Biology members, Marine Science Centre where the study was achieved.

\section{References}

Ahmed, M.H. (2017). Composition of the community of small fish in nursery areas and the impact of organic pollution in Garmet Ali river, Basrah, Iraq. M. Sc. Thesis, Coll. Agric., Univ. Basrah: 85pp. (In Arabic).

Ahmed, R.A.Z. (2015). Evaluation of organic pollution level and its impact on the diversity of benthic algae and the incidence of fish with foot paddles in three stations in Basrah Governorate. M.Sc. Thesis, Coll. Agric., Univ. Basrah, 139pp. (In Arabic).

Al-Aboodi, A.H.; Abbas, S.A. \& Ibrahim, H.T. (2018). Effect of Hartha and Najibia power plants on water quality indices of Shatt Al-Arab river, south Iraq. Appl. Water Sci., 8(64): 1-10.

Al-Hejuje, M.M. (1997). Distribution of heavy metals in water and sediments from Al-Ashar and Al-Khandak canals connected with Shatt Al-Arab river and their effects on algae. M. Sc. Thesis. Coll. Sci., Univ. Basrah: 104pp. (In Arabic).

Al-Hejuje, M.M. (2014). Application of water quality and pollution indices to evaluate the water and sediments status of the Middle part of Shatt Al-Arab river. Ph.D. Thesis, Coll. Sci. Univ. Basrah: 240pp.

Al-Imarah, F.J.M.; Alioui, Y.J. \& Mons, F.S. (2001). Monthly variations in nutrients and chlorophyll levels in the Shatt Al-Arab waters. J. Marine Mesopot., 16(1): 347357. (In Arabic). ?

Al-Kanani, H.M.A. (2017). Use of the palmer index and the organic pollution index for the environmental assessment of Shatt AlArab water, Iraq. M. Sc. thesis, Coll. Agric., Univ. Basrah: 94pp. (In Arabic).

Al-Saadi, H.A. (2006). Fundamental of ecology. First printing, Dar Al-Bazordi for printing and publishing, Amman-Jordan: 411pp (In Arabic).

Al-Shawi, E.J.M. (1999). Effect of thermal flows of thermal power plants on the presence and density of aquatic organisms in Basrah Governorate, Iraq. M. Sc. Thesis, Coll. Agric., Univ. Basrah: 77pp. . (In Arabic). 
Antoine, S.E. \& Al-Saadi, H.A. (1982). Limnological studies on the polluted Ashar canal and Shatt Al-Arab river at Basrah, Iraq. Int. Rev. Ges. Hydrobiol., 67(3): 405418.

APHA, American Public Health Association (2005). Standard methods for the examination of water and wastewater, $21^{\text {st }}$ Edition .Washington, D.C.: 733pp.

Boluda, R.; Quintainilla, J.F.; Bonilla, J.A.; Seaz, E. \& Goman, M. (2002). Application of the microtox test and pollution indices to the study of water toxicity in the Albufera Natural Park (Valencia, Spain). Chemosphere, 46: 355-369.

Chang, H. X.; Yang, Y.; Fang, P.; Pu, Z. \& Zed, R. (2006). Nitrogen removal from the eutrophic water by microbial-plant integrated system. J. Zhejiang Univ. Sci. B., 7(7): 521-531.

Davies, C.M.; Long, J.A.; Donald, M. \& Asbbolt, N.J. (1995). Survival of Fecal micro- organisms in marine and Fresh water sediments. Appl. and Environmental Microbiology. 61: 878-896.

Deijoux, C.R.; Doelstra, R. \& Wilkinson, P. (1981). Pollution in the Ecology and utilization of African inland waters edited by Symaens, J.; Burgis, M. and Goudet. UNEP Rep. Pros. Sexo., 2(1): 149-161.

EPA, Environmental Protection Agency (2001). Ambient Water Quality Criteria Recommendations Rivers and Streams in Nutrient, Eco region X: 28 pp.

Faragallah, H.M.; Askar, A.I.; Okbah, M.A. \& Moustafa, H.M. (2009). Physicochemical characteristics of the open Mediterranean sea water far about $60 \mathrm{Km}$ from Damietta harbor, Egypt. Journal of Ecology and The Natural Environment, 1(5): 106-119.
Hameed, A.H. \& Aljorany, Y.S. (2011). Investigation on nutrient behavior along Shatt Al-Arab River, Basrah, Iraq. J. Appl. Sci. Res., 7(8): 1340- 1345.

Hassan, W.F. (2013). The nitrogen and phosphate forms in water of Shatt Al-Arab river in Basrah, Iraq. Marsh Bull., 8(2): 182-192.

Iraqi Standard and Metrology (1980). System of river maintenance from pollution, No. 25 and associated instructions. Iraqi Waqae'e Magazine No. 2763 in 1980-3-13 Published in 28-7-1980.

Johnson, P.T.J. \& Chase, J.M. (2004). Parasites in the food. web linking amphibian malformations and aquatic eutrophication. Ecol. Letters, 7: 521-526.

Kouame, M.K.; Gnagne, T.; Konan, F.K.; Bony, Y.K. \& Gourene, G. (2012). Effects of treated agro-industrial effluents on physical and chemical characteristics of the receiving stream Wawa in southeastern Côte d'Ivoire. Int. J. Biol. Chem. Sci., 6(2): 871-886.

Liu, Q.; Mancl, K.M. \& Tuovinen, O.H. (2000). High fat wastewater remediation using layered sand filter biofilm systems. In Proceedings of the international symposium on animal, agricultural and food processing wastes, ASAE, St. Joseph, Michigan (pp. 242-248).

Lomoljo, R.M.; Ismail, A. \& Yap, C.K. (2009). Nitrate, Ammonia and Phosphate concentrations in the surface water of Kuala Gula Bird Sanctuary, west coast of Peninsular Malaysia. Pertanika J. Trop. Agric. Sci., 32(1): 1-5.

Mahmood, A.A. (2008). Concentrations of pollutants in water, sediments and aquatic plants in some wetlands in South of Iraq. 
Ph.D. Thesis, Coll. Sci., Univ. Basrah: 244pp. (In Arabic).

Moyel, M.S. \& Hussain, N.A. (2015). Water quality assessment of the Shatt Al-Arab river, southern Iraq. Journal of Coastal Life Medicine, 3(6): 459-465..

Nazal, A.M. (2016). Efficiency of Aquatic plant, Typha domingensis Pars. and the algae attached to the improvement of water quality in the southeastern part of Hor AlHammar. M. Sc. Thesis, Coll. Agriculture, Univ. Basrah: 116pp. (In Arabic).

Onyema, I.C.; Nkwoji, J.A. \& Eruteya, O.J. (2007). The water chemistry and plankton dynamics of a tropical high-energy erosion beach in Lagos. J. American Sci., 6(1): 111-122.

Partow, H. (2001). The Mesopotamian Marshlands: Demise of an Ecosystem. Early Warning and Assessment Technical Report UNEP/DEWA/TR.01-3 Rev. 1.

Prathumratana, L.; Sthiannopkao, S. \& Kim, K.W. (2008). The relationship of climatic and hydrological parameters to surface water quality in the Mekong River. Environ. Int., 34: 860-866.

Radwan, M. (2007). Evaluation of different water quality parameters for the Nile River and the different drains. $9^{\text {th }}$ Int. Water Technol. Conf., IWTC9, Sharm El-Sheikh, Egypt: 1293-1303.
Rahul, U.; Arvind, P.K. \& Upadhyay, S.K. (2013). Assessment of lake water quality by using Palmer and Trophic State Index- a Case study of upper lake, Bhopal, India. Int. Res. J. Environ. Sci., 2(5): 1-8.

Rakocevic, J. (2012). Spatial and temporal distribution of phytoplankton in lake Skadar, Arch. Biol. Sci. Belgrade, 64(2): 585-595.

Saleem, F.M. \& Hussain, N.A. (2013). Assessment of organic pollution levels in the northern and middle parts of Shatt AlArab River applying modified organic pollution index (OPI) Basrah J. Agric. Sci., 26(1): 207-221. (In Arabic).

Strickland, J.D.H. \& Parsons, T.R. (1972). A practical Handbook of Sea-water Analysis. Bull. 167. Fish Res. Board: 310pp.

Varol, M.; Gökot, B.; Bekleyen, A. \& Șen, B. (2011). Water quality assessment and apportionment of pollution sources of Tigris River (Turkey) using multivariate statistical techniques - A case study. River Res. Appl., Published online in Wiley Online Library (Wileyonlinelibrary.com), DOI: 10.1002/rra.1533.

Yaseen, B.R.; Al Asaady, K.A.; Kazem, A.A. \& Chaichan, M.T. (2016). Environmental impacts of salt tide in Shatt Al-Arab, Basrah, Iraq. J Environ Sci. Toxicology Food Technol., 10(1): 35-43. 